\title{
A new genus of Liocranidae (Arachnida: Araneae) from Tajikistan
}

\author{
Yuri M. Marusik ${ }^{1,2,3}$, Alexander A. Fomichev ${ }^{4}$ \\ I Institute for Biological Problems of the North RAS, Portovaya Str. 18, Magadan, 685000, Russia \\ 2 Department of Zoology \& Entomology, University of the Free State, Bloemfontein 9300, South Africa \\ 3 Zoological Museum, Biodiversity Unit, FI-20014 University of Turku, Finland \\ 4 Altai State University, 61 Lenina Prospect, Barnaul, 656049, Russia \\ Corresponding author: Yuri M. Marusik (yurmar@mail.ru)
}

Academic editor: R. Yakovlev| Received 15 October 2020 | Accepted 29 October 2020 | Published 4 December 2020

http://zoobank.org/C5FA8CFC-953F-43EE-8CEC-7F08B23A39C1

Citation: Marusik YuM, Fomichev AA (2020) A new genus of Liocranidae (Arachnida: Araneae) from Tajikistan. Acta Biologica Sibirica 6: 583-594. https://doi.org/10.3897/abs.6.e59687

\begin{abstract}
A new genus, Platnick gen. n., with three new species, $P$. shablyai sp. n. ( $\hat{\delta}$, type species), $P$. astana sp. n. () and P. sanglok sp. n. (守), are described from Tajikistan. The male of the type species has a unique pair of longitudinal ventral postgastral scuta. Females have such scuta also, but they are much shorter. The new genus is placed in Liocranidae Simon, 1897. A discussion on the subfamilies of Liocranidae and comments on the family-group names are provided.
\end{abstract}

\section{Keywords}

Aranei, biodiversity, Central Asia, Dionycha, morphology, Oedignathinae, spider, taxonomy

\section{Introduction}

Liocranidae Simon, 1897 is a relatively small spider family with 290 extant named species belonging to 32 genera distributed worldwide (WSC 2020). This family is poorly delimited, with an unclear number of subfamilies and currently containing genera that have ping-ponged from family to family (cf. Deeleman-Reinhold

Copyright Yuri M. Marusik, Alexander A. Fomichev. This is an open access article distributed under the terms of the Creative Commons Attribution License (CC BY 4.0), which permits unrestricted use, distribution, and reproduction in any medium, provided the original author and source are credited. 
2001, Bosselaers and Jocqué 2013 and Ramírez 2014). The most recent publications mention different names. Bosselaers and Jocqué (2013) reported two subfamilies: Cybaeodinae Simon, 1893 and Liocraninae Simon, 1897; Ramírez (2014), in the fundamental revision of the Dionycha, mentioned only one subfamily name Oedignathinae Simon, 1897 and did not discuss the division of Liocranidae to subfamilies or tribes. Five genera of Liocranidae, all belonging to Liocraninae, are known from Central Asia: Agraecina Simon, 1932, Agroeca Westring, 1861, Apostenus Westring, 1851, Liocranum L. Koch, 1866 and Mesiotelus Simon, 1897 (Mikhailov 2013; WSC 2020); however, none are known from Tajikistan. While studying spiders collected in Tajikistan, we found several specimens of Phrurolithidae- (a similar, also poorly delimited family)/Liocranidae-like spiders, belonging to three species from one genus, which do not correspond to any known genus of either Phrurolithidae Banks, 1892 (a family recently reviewed in Central Asia by Zamani and Marusik 2020) or Liocranidae. The males of this genus have a pair of unique, large, longitudinal postgastral scuta, a character unknown in all other spiders, and both sexes are somewhat dorsoventrally flattened. Scanning electron microscopy (SEM) of the male palp revealed the presence of the tegular apophysis. This, and the similarity of abdominal scuta with some genera of Oedignathinae led us to the conclusion that these new species belong to Liocranidae sensu Ramírez (2014). The goals of this paper are to provide comments on the family group names of Liocranidae, briefly discuss the subfamilies, their authorship, and describe a new genus with three new species of this genus.

\section{Material and methods}

Specimens were photographed using an Olympus Camedia E-520 camera attached to an Olympus SZX16 stereomicroscope or to the eye piece of an Olympus BH2 transmission microscope, and a SEM JEOL JSM-5200 scanning electron microscope at the Zoological Museum of University of Turku, Finland. Digital images were prepared using Helicon Focus 7.5.8 and/or Zerene Stacker version 1.04 image stacking software. Illustrations of endogynes and palps were made after clearing them in a $10 \%$ $\mathrm{KOH}$ aqueous solution and in lactic acid, respectively. Lengths of leg segments were measured on the dorsal side. All measurements are given in millimeters. All types are deposited in the Zoological Museum of the Moscow State University (ZMMU).

\section{Abbreviations}

Leg segments: Fe - femur, Mt - metatarsus, $\mathrm{Pt}$ - patella, $\mathrm{Ta}$ - tarsus, $\mathrm{Ti}$ - tibia. Spination: $\mathrm{d}$ - dorsal, $\mathrm{pv}$ - proventral, $\mathrm{r}$ - retrolateral, $\mathrm{rv}$ - retroventral, $\mathrm{v}$ - ventral. 


\section{Taxonomic survey}

\section{Family Liocranidae Simon, 1897}

\section{Family-group names in Liocranidae}

In the current literature, we found five family-group names provided for genera that are currently placed in Liocranidae (WSC 2020): Cybaeodinae Simon, 1893 (WSC 2020), Liocraninae Simon, 1897, Oedignathinae Simon, 1897 (Ramírez 2014), Thamphilinae Thorell, 1897 and Sphingiinae (Deeleman-Reinhold 2001). Only three names are mentioned in the catalog of Bonnet (1961): Cybaeodinae, Liocraninae and Oedignathinae. It seems that Sphingiinae is a nomen nudum and was suggested by Deeleman-Reinhold (2001) as a replacement name for Thamphilinae (Thamphilus Thorell, 1895 is considered a junior synonym of Sphingius Thorell, 1890). For some reasons Thamphilinae and Oedignathidae Thorell, 1897 are not mentioned among family group names in Bonnet (1961). The publication dates of Simon's and Thorell's works with Oedignathidae Thorell, 1897, Oedignatheae Simon, 1897 and Liocraninae Simon, 1897 reveal that Simon's names were published after Thorell's Oedignathidae. Below we list all taxonomic names currently considered within Liocranidae:

Cybaeodinae Simon, 1893: 341 (key), 387 (description); Tucker 1923: 253, 431;

Bonnet 1956: 1297; Bonnet 1961: 12; Platnick and Di Franco 1992: 1. Liocraninae Simon, 1897: 23-24; Bonnet 1957: 2540; Bonnet 1961: 13.

Liocranidae Lehtinen, 1967: 312, 340 (raised to family level); Deeleman-Reinhold 2001: 399; Ramírez 2014: 343.

Oedignatheae Simon, 1897: 178 (key), 187 (description) [date of publication

15.II.1897]; Bonnet 1958: 3137; Bonnet 1961: 1218; Ramírez 2014: 343.

Oedignathidae Thorell, 1897: 197 [description is missing, date of publication 2.I.1897]. Sphingiinae Deeleman-Reinhold, 2001: 465 [nomen nudum]; Zhang et al. 2009: 31. Thamphilinae Thorell, 1897: 230 (based on Thamphilus 1895=Sphingius Thorell, 1890).

Although Oedignathidae Thorell, 1897 has one month priority over Liocraninae Simon, 1897, article 35.5 of the ICZN allows the junior name to remain if it has prevailing usage: "If after 1999 a name in use for a family-group taxon (e.g. for a subfamily) is found to be older than a name in prevailing usage for a taxon at higher rank in the same family-group taxon (e.g. for the family within which the older name is the name of a subfamily) the older name is not to displace the younger name". Until recently, Oedignatha Thorell, 1881 was considered to belong in Corinnidae and was transferred to Liocranidae by Ramírez (2014). 


\section{Oedignathinae Thorell, 1897}

\section{Comments}

The genera currently (WSC 2020) considered in Liocranidae that share characters also found in Oedignatha, such as the epigastric scutum forming a petiolar tube, postgastral scuta connected to book-lung spiracles and males with a large dorsal scutum, are: Koppe Deeleman-Reinhold, 2001; Oedignatha Thorell, 1881; Platnick gen. n., Sesieutes Simon, 1897; Sphingius Thorell, 1890; Sudharmia Deeleman-Reinhold, 2001 and Teutamus Thorell, 1890. The characters mentioned above are not known in Liocraninae sensu stricto. Ramírez (2014) considered the aforementioned genera and also Jacaena Thorell, 1897 as closely related and belonging to the Teutamus group, although Sudharmia, Oedignatha and Koppe were placed in this group with some reservations.

Genera considered by us to belong in Oedignathinae or the Teutamus group (sensu Ramírez, 2014) were until recently placed in Corinnidae and Phrurolithinae (a subfamily of Liocranidae, raised to family level by Ramírez (2014)). Historically, different genera have been placed in Clubionidae, Gnaphosidae, Micariinae Simon, 1897 and Molycriae Simon, 1897 (see Deeleman-Reinhold 2001). Seven genera that we consider to belong to Oedignathinae are known from Central Asia-from Tajikistan, south to Sri Lanka and southeast to Samoa. Only two Oedignatha species, the type species O. scrobiculata Thorell, 1881 and O. mogamoga Marples, 1955, have a wider distribution than mentioned above, known outside of the region due to introduction (cf. WSC 2020).

\section{Platnick gen. $\mathbf{n}$.}

http://zoobank.org/824BDBFE-0DCA-4EF3-A850-BAF54807FE09

Type species. Platnick shablyai sp. n. from Tajikistan.

Etymology. The genus is named after the late Norman I. Platnick (1951-2020) who made unprecedented contributions to arachnology, including creating the World Spider Catalog. The gender is masculine.

Diagnosis. The new genus is most similar to the Southeast Asian genera Oedignatha Thorell, 1881, Sesieutes Simon, 1897 and Sphingius Thorell, 1890. The male of the new genus differs from all other Oedignathinae by having a pair of longitudinal (longer than wide) ventral scuta (vs. absent). In addition, the male can be distinguished by having an antero-ventral femoral extension of the palp (vs. lacking) and a helical (screw threading) embolus embedded in a collar $(\mathrm{Cl})$ (vs. filamentous embolus, lacking collar). Females of Platnick gen. n. differ from Oedignatha by lacking a dorsal scutum and having small (smaller than the epigyne) postgastral scuta (vs. scuta larger than the epigyne, transverse and almost touching each other).

Description. Small, body length 2.1 in male and 2.18-2.35 in females; carapace 0.96 long in male, and 0.86-1.03 in females. Prosoma uniformly colored, flat, $>2$ 
times longer than high, carapace rather flat; carapace length/height ratio $>3$; carapace covered with fine granulation; fovea short, longitudinal, about as long as AME diameter; margin with small spines. Carapace and sternum fused. Sternum oval, posterior edge truncate, slightly wider than labium; sternum covered with fine pits bearing setae. Female palp with claw. Chelicera covered with small spines anteriorly, basal part extended anteriorly. Labium about 1.5-1.6 times longer than wide. Maxillae slightly concave, rebordered mesally. Legs uniformly colored, with darker femora and coxae I; femora I-II and metatarsi IV without spines; tibiae I-II with 4-6 pairs of ventral spines; metatarsi I-II with a pair of spines. Spine locking mechanism barely developed. Metatarsi III-IV with preening brush on distal half. Leg formula 4123. Leg I (leg I/carapace length) longer in females (2.5-2.6) than in male (2.3).

Abdomen elongate and flat, 1.5-2 times longer than wide and $>2$ times longer than high, uniformly colored. Both sexes with epigastral scutum, in male encircling petiolus, in female scutum encircling ventral and lateral parts. Dorsum of male almost entirely covered with brown scutum; female abdomen pale, covered with small setae, with a pair of sigillae medially. Venter of abdomen in male with epigastric scutum rebordered posteriorly, postgaster with pair of longitudinal scuta tapering posteriorly, length/maximum width is about 2 , connected to epigastral scutum near postero-lateral edge of book-lung opercula. Female with a pair of small transverse postgastral scuta attached to epigastral scutum near postero-lateral edge of booklung opercula. In both sexes, epigastral scuta extend into petiolar tube. Spinnerets not darker than venter.

Male palp: femur 2.3 times longer than wide, with distal ventral extension $(\mathrm{Ve})$, femur slightly shorter than cymbium; patella modified, with retrolateral outgrowth $(\mathrm{Po})$, dorsal length longer than tibia; tibia as long as wide in dorsal view, with short prolateral apophysis $(\mathrm{Pa})$; cymbium oval, about 1.6 times longer than wide; bulb oval, about 1.5 times longer than wide; sperm duct $(S d)$ long and wide, encircling retrolateral and posterior edge of tegulum, its broad part terminating at about 8:30 oclock position; tegulum with apophysis $(\mathrm{Ta})$, with claw-like tip directed retrolaterally; conductor small $(\mathrm{Cn})$, weakly sclerotized; embolus $(\mathrm{Em})$ located medially, embedded in tegulum, tegulum forms a collar $(\mathrm{Cl})$ around embolus, embolus with weakly sclerotized helicoid tip.

Epigyne with distinct, or indistinct fovea $(F o)$, with separate copulatory openings $(\mathrm{Co})$; receptacles $(R e)$ tubular; receptacular glands $(R g)$ thick, extend anteriorly, close together; fertilization ducts $(F d)$ located posteriorly.

Comment. We were unable to match the species known only from the male with either morphospecies represented by females. All three specimens have different spination and were not collected from the same localities. Therefore, we describe the females as a different species than the male, understanding that in the future, one of the females may be synonymized with the generotype P. shablyai sp. n.

Composition. Platnick astana sp. n., P. sanglok sp. n. and P. shablyai sp. n.

Distribution. All three species were collected in the Khatlon Region of Tajikistan (Figs 33-34). 
Platnick shablyai sp. n.

http://zoobank.org/CA063C93-70FA-4155-8192-1BE8DCD0D8C4

Figs 1-13, 26, 33-34

Type. Holotype $\hat{\delta}$ (ZMMU), TAJIKISTAN, Khatlon Region, Dzhilantau Mt. Range, $2 \mathrm{~km}$ E from Kuybul'on Village, $37^{\circ} 53.970^{\prime} \mathrm{N}, 6^{\circ} 23.155^{\prime} \mathrm{E}$, dry stony shiblyak shrubland with rocks, 970-1200 m, 14.04.2019 (A.A. Fomichev).

Etymology. The species is named after the entomologist Vitaliy O. Shablya (Moscow, Russia), who organized the expedition to Tajikistan in which the new species was collected.

Diagnosis. Same as for the genus.

Description. Male. Total length 2.1. Prosoma 0.46 high. Carapace: 0.96 long, 0.74 wide, 0.3 high. Prosoma and chelicerae brown. Legs and palps pale yellow with darker coxa and femur I. Abdomen with brownish dorsal scutum almost entirely covering dorsum. Epigastral scutum encircling petiolus. Postgastral scuta as shown in Fig. 2 and described for the genus.

Palp as in Figs 6-13. See description of the genus.

\begin{tabular}{|c|c|c|c|c|c|c|c|c|c|c|}
\hline \multicolumn{7}{|c|}{ Leg measurements: } & \multicolumn{4}{|c|}{ Leg spination: } \\
\hline & $\mathrm{Fe}$ & Pt & $\mathrm{Ti}$ & Mt & $\mathrm{Ta}$ & Total & & $\mathrm{Fe}$ & $\mathrm{Ti}$ & Mt \\
\hline I & 0.64 & 0.34 & 0.53 & 0.37 & 0.37 & 2.25 & I & - & pv4 rv4 & pv1 rvl \\
\hline II & 0.57 & 0.33 & 0.46 & 0.34 & 0.34 & 2.04 & II & - & pv4 rv3 & pv1 rv1 \\
\hline III & 0.46 & 0.24 & 0.3 & 0.33 & 0.34 & 1.67 & III & $\mathrm{d} 1$ & $\mathrm{v} 1$ & pv1 \\
\hline IV & 0.61 & 0.33 & 0.51 & 0.5 & 0.44 & 2.39 & IV & d1 & $\mathrm{r} 1$ & - \\
\hline
\end{tabular}

Habitat. The holotype was collected in shiblyak shrubland. Shiblyak is a kind of vegetation similar to those called garrigue (https://en.wikipedia.org/wiki/Garrigue) or maquis shrubland (https://en.wikipedia.org/wiki/Maquis_shrubland), composed of deciduous xerophilous shrubs and small trees.

Distribution. Known from the type locality only (Figs 33-34).

\section{Platnick sanglok sp. n.}

http://zoobank.org/FA948D98-2431-4342-944D-3D3462FCC73C Figs 14, 16, 18, 20, 29-34

Type. Holotype 우 (ZMMU), TAJIKISTAN, Khatlon Region, Dangara Distr., SW slope of Sanglogh (=Sanglok) Mt. Range, 38 $13.091^{\prime} \mathrm{N}, 69^{\circ} 14.282^{\prime} \mathrm{E}$, clay-sand cliffs along road and among litter under Artemisia, 1362 m, 30.04.2015 (Y.M. Marusik).

Etymology. The species epithet is a noun in apposition taken from the type locality.

Diagnosis. The new species differs from those of $P$. astana sp. n. by the indistinct fovea and unconcealed copulatory openings $(\mathrm{Co})$ (vs. fovea distinct, copulatory openings concealed by hoods), as well as by the copulatory ducts $(C d)$ directed posteriorly and the short glands of the receptacles $(R g)$ not extended anteriorly as much as the 


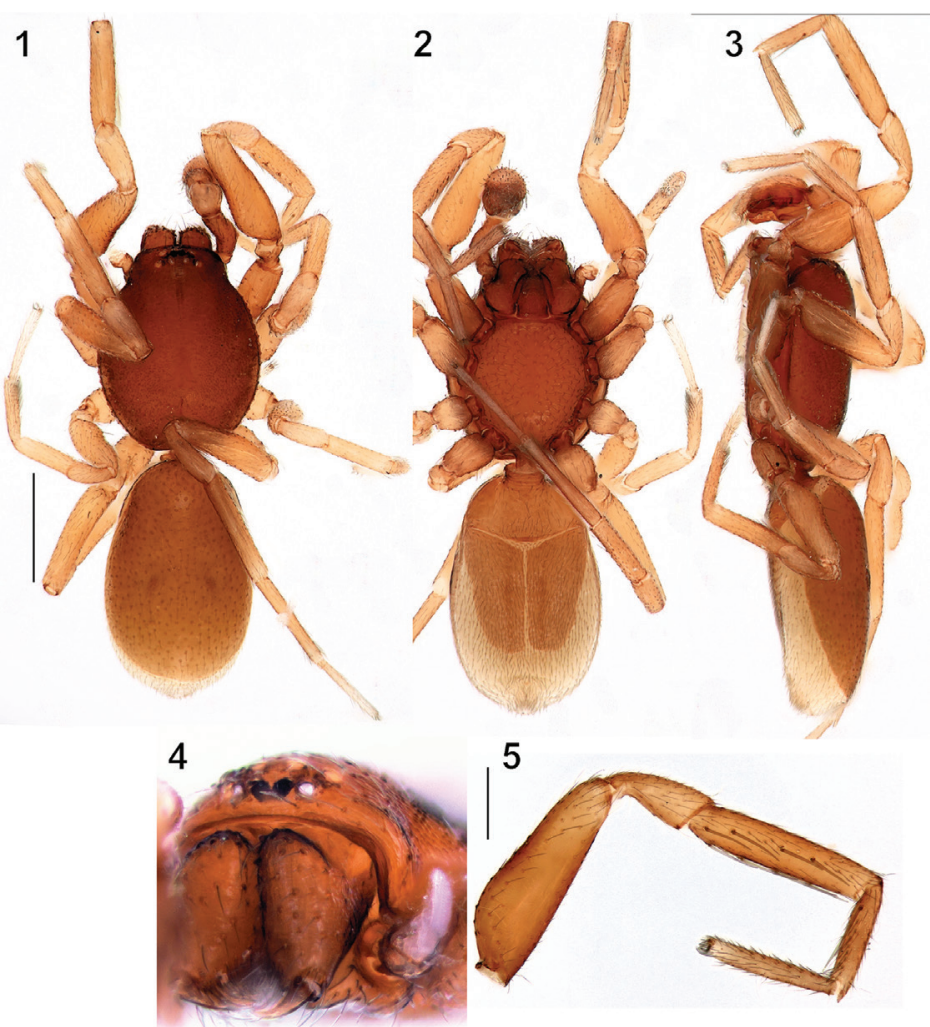

Figures I-5. Male of Platnick shablyai sp. n.: I-3 - habitus, 4 - cephalic part, 5 - leg I. I - dorsal, 2 - ventral, 3 - lateral, 4 - frontal, 5 - prolateral. Scale bars: $0.5 \mathrm{~mm}$ (I ); $0.2 \mathrm{~mm}$ (5).

receptacles ( $v s$. copulatory ducts directed anteriorly, and glands of receptacles located anterior to receptacles). The two species differ by the spination of tibia II: $P$. sanglok sp. n. has 5 pairs of ventral spines, whereas $P$. astana sp. n. has 4 pairs.

Description. Female. Total length 2.18. Prosoma 0.5 high. Carapace: 1.03 long, 0.81 wide, 0.33 high. Prosoma and chelicerae brown. Legs and palps pale yellow, femora and coxae I darker than other segments. Abdomen and spinnerets white. Postgastral scuta elongate, ovoid, about 4 times longer than wide.

Epigyne as in Figs 29-32; fovea indistinct, copulatory openings ( $\mathrm{Co}$ ) unconcealed, hood absent; copulatory ducts directed posteriorly; glands of receptacles short, shorter than anterior extension of receptacles, diverging.

\begin{tabular}{|c|c|c|c|c|c|c|c|c|c|c|}
\hline \multicolumn{7}{|c|}{ Leg measurements: } & \multicolumn{4}{|c|}{ Leg spination: } \\
\hline & $\mathrm{Fe}$ & $\mathrm{Pt}$ & $\mathrm{Ti}$ & Mt & $\mathrm{Ta}$ & Total & & $\mathrm{Fe}$ & $\mathrm{Ti}$ & Mt \\
\hline I & 0.77 & 0.41 & 0.66 & 0.43 & 0.43 & 2.7 & I & - & pv6 rv5 & d1 pv1 rvl \\
\hline II & 0.7 & 0.37 & 0.57 & 0.41 & 0.41 & 2.46 & II & - & pv5 rv5 & pv1 rv1 \\
\hline III & 0.53 & 0.3 & 0.4 & 0.4 & 0.37 & 2.0 & III & $\mathrm{d} 1$ & pvl v1 & pv1 \\
\hline IV & 0.76 & 0.4 & 0.66 & 0.61 & 0.5 & 2.93 & IV & d1 & pv1 r1 & - \\
\hline
\end{tabular}

Distribution. Known from the type locality only (Figs 33-34). 
6

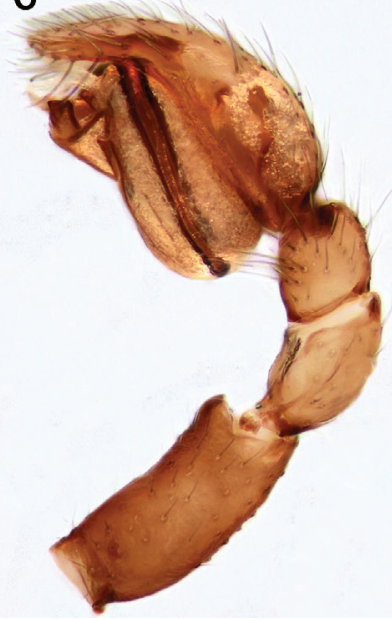

9
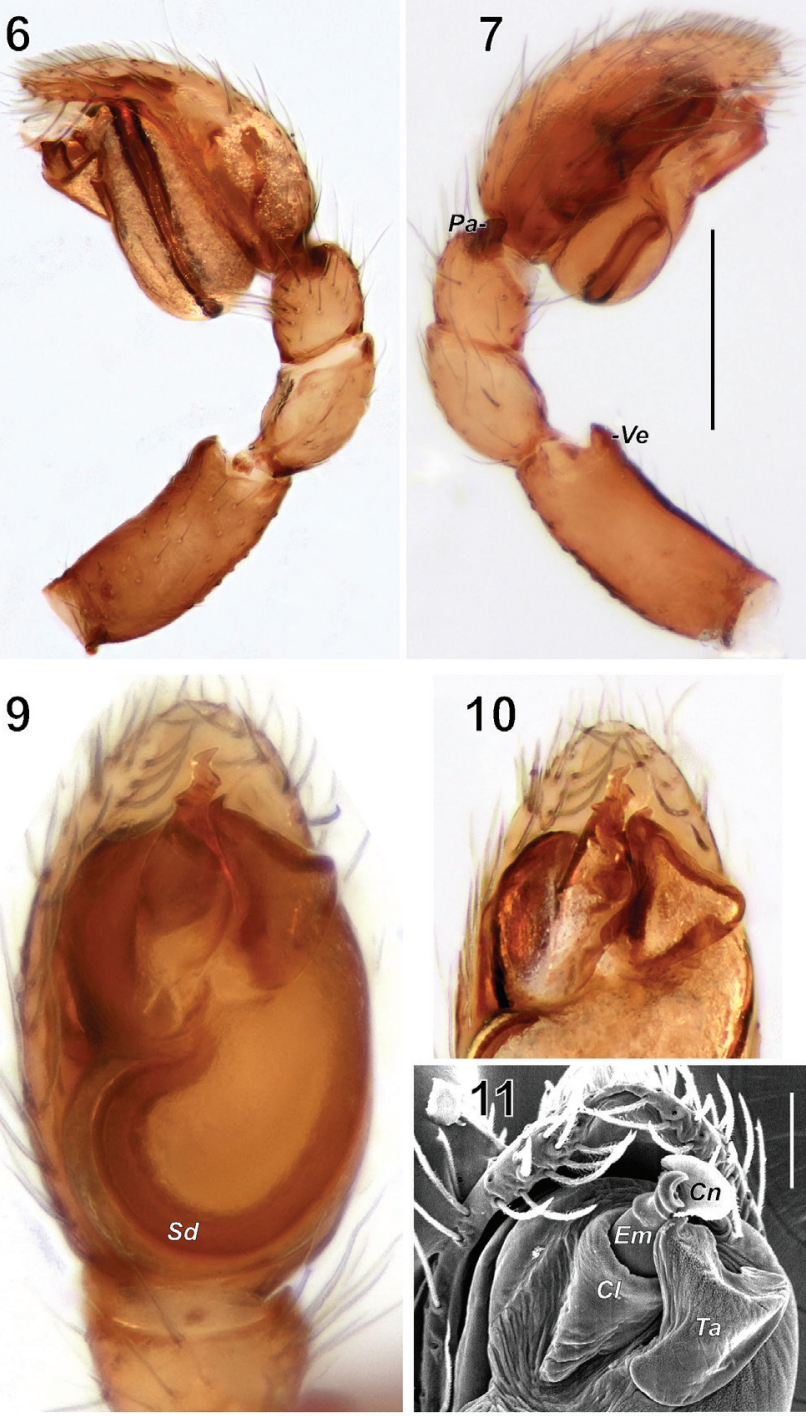

8

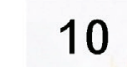

10
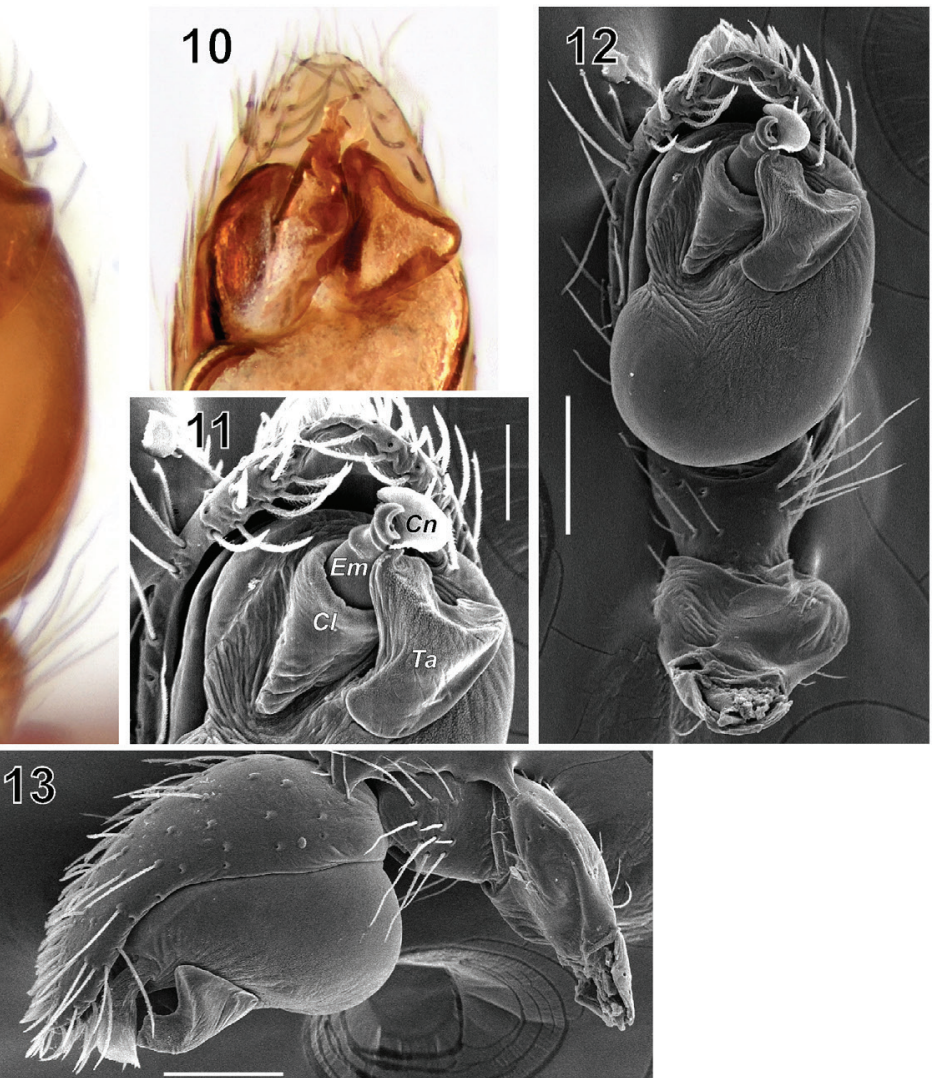

Figures 6-13. Male palp of Platnick shablyai sp. n.: 6-9, I 2, I3 - whole palp, I 0, I I - terminal part. 6, I 3 - Retrolateral, 7 - prolateral, 8 - dorsal, 9-I 2 - ventral. Abbreviations: $\mathrm{Cl}$ - tegular collar, $\mathrm{Cn}$ - conductor, $\mathrm{Em}$ - embolus, $\mathrm{Pa}$ - prolateral apophysis of tibia, $\mathrm{Po}$ - retrolateral outgrowth of patella, $S d$ - sperm duct, $\mathrm{Ta}$ - tegular apophysis, $\mathrm{Ve}$ - ventral extension of femur. Scale bars: $0.2 \mathrm{~mm}$ (7); $0.05 \mathrm{~mm}$ (I I ); $0.1 \mathrm{~mm}$ ( I 2, I 3). 

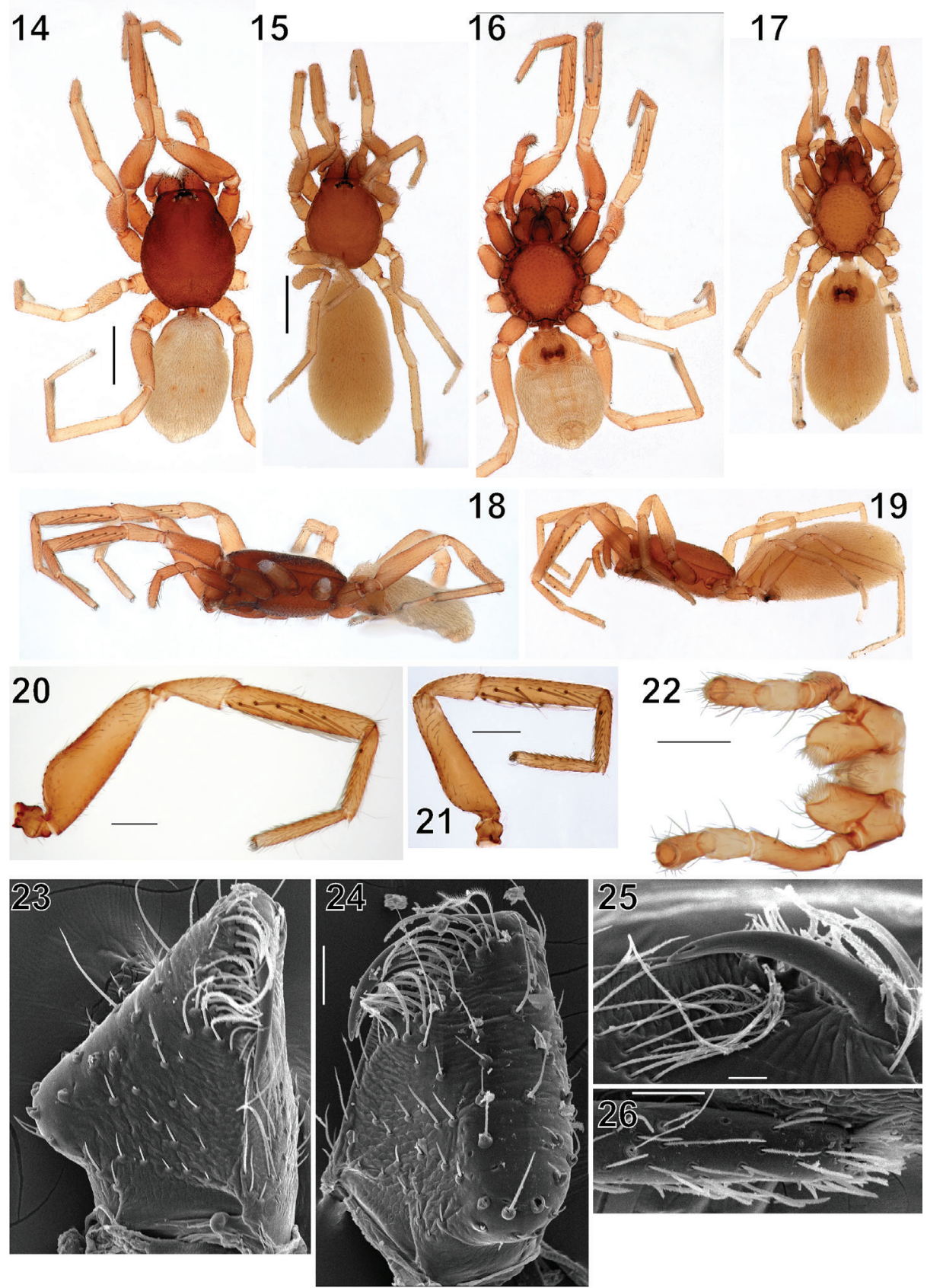

Figures I 4-26. Female habitus and details: | 4, 16, I 8, 20 - Platnick sanglok sp. n. I 5, I 7, I9, 2 I-25 - P. astana sp. n. 26 - P. shablyai sp. n. I4, I5 - Habitus, dorsal, I 6, 17 - ditto, ventral, I 8, 19 - ditto, lateral, 20, 2 I - female leg I, prolateral, 22 - female maxillae and palps, dorsal, 23, 24 - female chelicera, mesal and anterior, 25 - the fang of the female chelicera, posterior, $\mathbf{2 6}$ - leg I Ta of the male. Scale bars: $0.5 \mathrm{~mm}(\mathbf{I} \mathbf{4}, \mathbf{I} \mathbf{5})$; $0.2 \mathrm{~mm}(\mathbf{2 0}, \mathbf{2 2})$; $0.05 \mathrm{~mm}(\mathbf{2 4}, \mathbf{2 6}) ; 0.02 \mathrm{~mm}(\mathbf{2 5})$. 

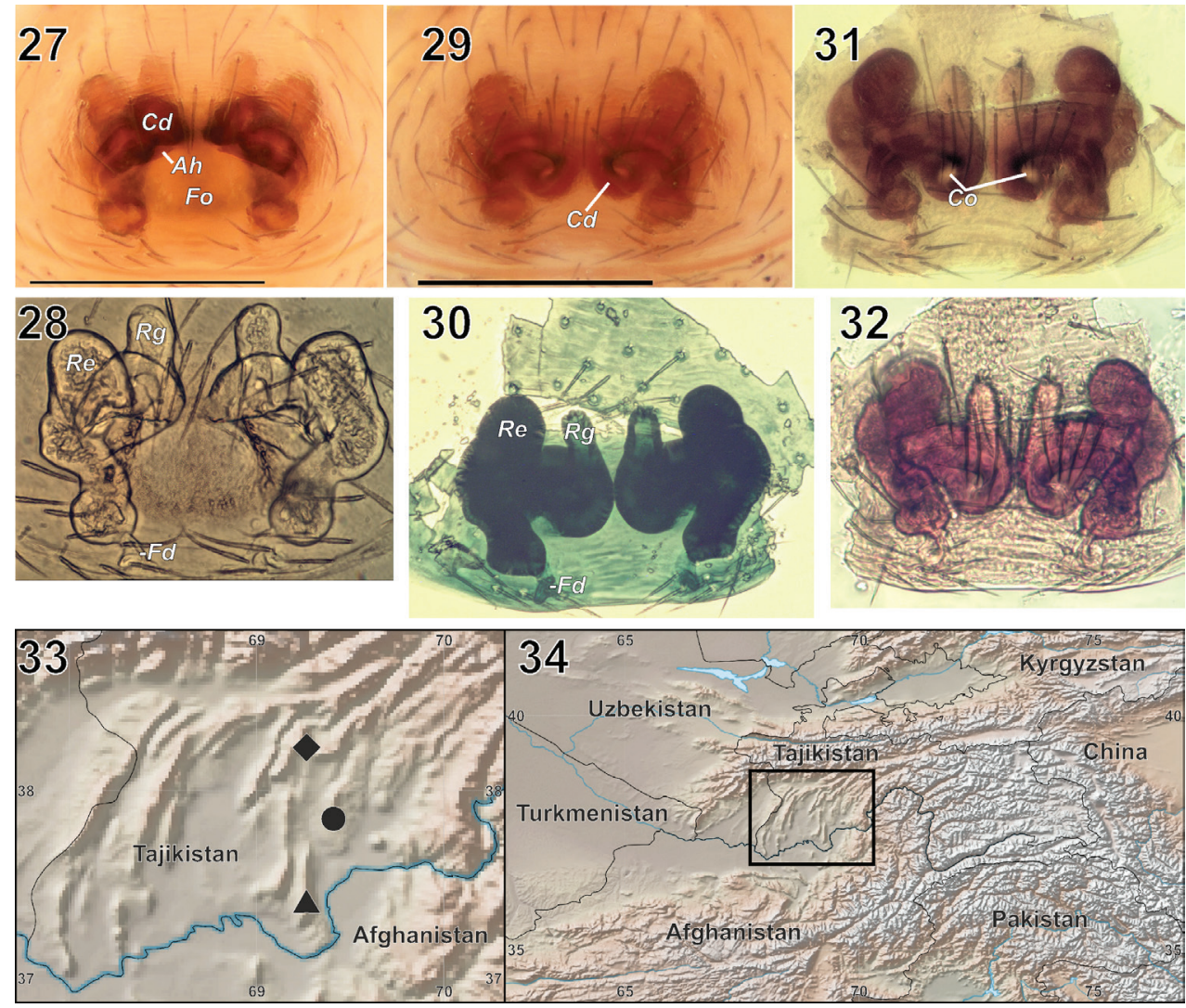

Figures 27-34. Epigynes: 27, 28 - Platnick astana sp.n.; 29-32 - P. sanglok sp.n.; 33, 34 - collecting localities of Platnick species. 27, 29 - Intact, ventral, 3 I, 32 - macerated, ventral, 28, $\mathbf{3 0}$ - macerated, dorsal. Abbreviations: $A h$ - anterior hood, $C d$ - copulatory ducts, $C o$ - copulatory opening, $F d$ - fertilization duct, $F o$ - fovea, $R e$ - receptacle, $R g$-receptacle gland. P. shablyai sp. n. - circle, P. astana sp. n. - triangle, P. sanglok sp. n. - diamond. Frame on Fig. 34 refers to Fig. 33. Scale bars: $0.2 \mathrm{~mm}(\mathbf{2 7}, \mathbf{2 9})$.

\section{Platnick astana sp. $\mathrm{n}$.}

http://zoobank.org/D3A9B738-19A0-4DA2-BD1C-A77C7015091B

Figs $15,17,19,21-25,27,28,33,34$

Type. Holotype o (ZMMU), TAJIKISTAN, Khatlon Region, Pyandzh Karatau Mt. Range, Astana Mt., $37^{\circ} 23.202^{\prime} \mathrm{N}, 69^{\circ} 14.810^{\prime} \mathrm{E}, 1674 \mathrm{~m}, 4.05 .2015$ (S.L. Zonstein).

Etymology. The species epithet is a noun in apposition taken from the type locality.

Diagnosis. See diagnosis for P. sanglok sp. n.

Description. Female. Total length 2.35. Prosoma 0.43 high. Carapace: 0.86 long, 0.66 wide, 0.3 high. Carapace, maxillae, labium and chelicerae yellow-brown. Ster- 
num dark yellow. Palps and legs light yellow with darker femur and coxa I. Legs IIIIV lighter than others. Abdomen and spinnerets beige. Postgastral scuta elongate, diamond-shaped, about 3 times longer than wide.

Epigyne as in Figs 27-28; fovea distinct, anterior hoods $(A h)$ conceal copulatory openings; copulatory ducts directed anteriorly; glands of receptacles separated, parallel, longer than anterior extension of receptacles.

\begin{tabular}{|c|c|c|c|c|c|c|c|c|c|c|}
\hline \multicolumn{7}{|c|}{ Leg measurements: } & \multicolumn{4}{|c|}{ Leg spination: } \\
\hline & $\mathrm{Fe}$ & Pt & $\mathrm{Ti}$ & Mt & $\mathrm{Ta}$ & Total & & $\mathrm{Fe}$ & $\mathrm{Ti}$ & Mt \\
\hline I & 0.61 & 0.33 & 0.53 & 0.37 & 0.36 & 2.2 & I & - & pv5 rv5 & pv1 rv1 \\
\hline II & 0.57 & 0.31 & 0.46 & 0.34 & 0.36 & 2.04 & II & - & pv4 rv4 & pv1 rv1 \\
\hline III & 0.44 & 0.24 & 0.33 & 0.33 & 0.34 & 1.68 & III & d1 & rvl & - \\
\hline IV & 0.64 & 0.33 & 0.56 & 0.54 & 0.46 & 2.53 & IV & d1 & pvl & - \\
\hline
\end{tabular}

Distribution. Known from the type locality only (Figs 33-34).

\section{Acknowledgements}

We thank Vitaliy O. Shablya (Moscow, Russia), Murod Saidov and Rustam Muratov (both from Dushanbe, Tajikistan) for organizing expeditions to Tajikistan in 2015 and 2019 in which the material treated here was collected. Special thanks to Sergei L. Zonstein (Tel-Aviv, Israel) for great help in collecting. Also, we thank Seppo Koponen and Ilari Sääksjärvi (University of Turku, Finland) for providing museum facilities, Charles Haddad (Bloemfontein, South Africa) and Martin Ramírez (Buenos Aires, Argentina) for consultations regarding the placement of the new genus. Theo Blick (Hummental, Germany) provided us with the dates of Simon's and Thorell's publications. An earlier draft of the manuscript was reviewed by Martin Ramírez and Mikhail M. Omelko (Vladivostok, Russia), and Sarah Crews (San Francisco, USA) provided valuable comments on earlier versions of this manuscript and kindly checked the English of the final draft. We thank the reviewers and the editor for their comments on the manuscript.

\section{References}

Bonnet P (1956) Bibliographia araneorum. Analyse méthodique de toute la littérature aranéologique jusqu'en 1939. Tome II. Systématique des araignées (Étude par ordre alphabétique) (2me partie: C-F). Douladoure Toulouse, 919-1926 pp.

Bonnet P (1957) Bibliographia araneorum. Analyse méthodique de toute la littérature aranéologique jusqu'en 1939. Tome II. Systématique des araignées (Étude par ordre alphabétique) (3me partie: G-M). Douladoure Toulouse, 1927-3026 pp.

Bonnet P (1958) Bibliographia araneorum. Analyse méthodique de toute la littérature aranéologique jusqu'en 1939. Tome II. Systématique des araignées (Étude par ordre alphabétique) (4me partie: N-S). Douladoure Toulouse, 3027-4230 pp. 
Bonnet P (1961) Bibliographia araneorum. Analyse méthodique de toute la littérature aranéologique jusqu'en 1939. Tome III. Index alphabétiques, résultats - conclusions, considérations diverses. Douladoure Toulouse, $591 \mathrm{pp}$.

Bosselaers J, Jocqué R (2013) Studies in Liocranidae (Araneae): a new afrotropical genus featuring a synapomorphy for the Cybaeodinae. European Journal of Taxonomy 40: 1-49. https://doi.org/10.5852/ejt.2013.40

Deeleman-Reinhold CL (2001) Forest spiders of South East Asia: with a revision of the sac and ground spiders (Araneae: Clubionidae, Corinnidae, Liocranidae, Gnaphosidae, Prodidomidae and Trochanterriidae [sic]). Brill Leiden, 591 pp.

Lehtinen PT (1967) Classification of the cribellate spiders and some allied families, with notes on the evolution of the suborder Araneomorpha. Annales Zoologici Fennici 4: 199-468.

Mikhailov KG (2013) The spiders (Arachnida: Aranei) of Russia and adjacent countries: a non-annotated checklist. Arthropoda Selecta, Supplement 3: 1-262.

Platnick NI, Di Franco F (1992) On the relationships of the spider genus Cybaeodes (Araneae, Dionycha). American Museum Novitates 3053: 1-9.

Ramírez MJ (2014) The morphology and phylogeny of dionychan spiders (Araneae: Araneomorphae). Bulletin of the American Museum of Natural History 390: 1-374. https:// doi.org/10.1206/821.1

Simon E (1893) Histoire naturelle des araignées. Deuxième édition, tome premier. Roret, Paris, $257-488 \mathrm{pp}$.

Simon E (1897) Histoire naturelle des araignées. Deuxième édition, tome second. Roret, Paris, 1-192 pp.

Thorell T (1897). Viaggio di Leonardo Fea in Birmania e regioni vicine. LXXIII. Secondo saggio sui Ragni birmani. I. Parallelodontes. Tubitelariae. Annali del Museo Civico di Storia Naturale di Genova (2) 17 [=37]: 161-267.

Tucker RWE (1923) The Drassidae of South Africa. Annals of the South African Museum 19: 251-437.

World Spider Catalog (2020) World Spider Catalog. Version 21.0. Natural History Museum Bern, online at http://wsc.nmbe.ch (accessed October 2020). https://doi.org/10.24436/2

Zamani A, Marusik YM (2020) A survey of Phrurolithidae (Arachnida: Araneae) in southern Caucasus, Iran and Central Asia. Zootaxa 4758(2): 311-329. https://doi.org/10.11646/ zootaxa.4758.2.6

Zhang F, Fu JY, Zhu MS (2009) Spiders of the genus Sphingius (Araneae: Liocranidae) from China, with descriptions of two new species. Zootaxa 2298: 31-44. 